\title{
Collective efficiency: a prerequisite for cluster development?
}

\author{
Rasmus Lema* \\ Department of Business and Management, \\ Aalborg University, \\ Frederikskaj 10, Building: B, Room: 3rd floor, \\ 2450 Copenhagen, Denmark \\ Email: lema@business.aau.dk \\ *Corresponding author
}

\section{Jan Vang}

Center for Industrial Production,

Aalborg University,

Frederikskaj 10, Building: B, Room: 116,

2450 Copenhagen, Denmark

Email: jan@business.aau.dk

\begin{abstract}
This paper is concerned with analysing the importance of collective efficiency for upgrading of clusters. The literature on collective efficiency ascribes it a crucial role in upgrading in clusters in developing countries. Little, however, is known about how insertion into global value chains affects the prospects of gaining collective efficiency hence, the paper analyses if Bangalore's insertion into global value chains has spurred or impeded collective efficiency in the cluster. Bangalore is considered a success case in terms of cluster upgrading in a developing country context. The paper finds mixed evidence of collective efficiency. Upgrading was mainly an aggregate outcome of an uncoordinated decentralised process managed by individual companies.
\end{abstract}

Keywords: collective efficiency; externalities; inter-firm organisation; joint action; global value chains; software industry; development; Bangalore.

Reference to this paper should be made as follows: Lema, R. and Vang, J. (2018) 'Collective efficiency: a prerequisite for cluster development?', World Review of Entrepreneurship, Management and Sustainable Development, Vol. 14, No. 3, pp.348-376.

Biographical notes: Rasmus Lema is an Associate Professor at the Department of Business and Management, Aalborg University. He works on innovation and development, ICT, sustainability, innovation systems, clusters and global value chains.

Jan Vang is an Associate Professor at the Center for Industrial Production, Aalborg University. He works on innovation, entrepreneurship and industrial clusters. 


\section{Introduction}

The literature on industrial clusters emerged in the 1990s (Porter, 1998) but has turned out to be remarkably prolific with an increase of cluster research in recent years (Dana et al., 2013; Delgado et al., 2015; Giuliani et al., 2013). Much of the literature uses the concept of externalities (Audretsch, 2003) which can be traced back to Marshall's initial contributions (Storper and Venables, 2004). The literature on clusters in developing countries (Gebreeyesus and Mohnen, 2013; Gutiérrez-Martínez et al., 2015; Rabellotti et al., 2014) also used externalities to inform the concept of collectively efficiency which has surfaced as a promising concept for explaining cluster-based development (Intarakumnerd and Vang, 2006; Giuliani and Morales, 2012).

A special issue of the journal World Development launched a strong argument that agglomerated firms in developing countries could acquire competitiveness through 'collective efficiency' (Humphrey, 1995, see also Parrilli, 2009 for a more general paper). The message was one of optimism as it was found that, in general, clusters in developing countries tended to be characterised by close inter-firm collaboration and effective private and public institutions.

The importance of collective efficiency for the competitiveness of local firms has been widely acknowledged. Yet in a second round of collective efficiency research, reported in another special issue of World Development, the discussion was brought several steps further (Schmitz and Nadvi, 1999). On one hand it prompted more optimism; the collective efficiency argument was strengthened as evidence showed that cooperative 'joint action' significantly improved performance and upgrading capabilities among cluster-based firms. On the other hand, it was found that collective efficiency was not an automatic outcome of clustering and that the trajectories of local clusters varied greatly in this regard (see also Chaminade and Vang, 2008a for a related theoretical conceptualisation). The second round of collective efficiency research also prompted a succeeding turn towards the study of clusters' linkages to the external world (Chaminade and Vang, 2008b; Iammarino and McCann, 2010; Iammarino et al., 2009; see Giuliani et al., 2014). Many case studies acknowledged such linkages, but there was no theorisation, let alone conclusions, with regard to how such linkages would affect the prospects for developing collective efficiency.

Subsequent studies of clusters in the developing world have been informed by a global value chain framework. For instance Schmitz's edited volume Local Enterprises in the Global Economy (2004) centred on the question of how insertion into global value chains affect upgrading in clusters (see also Humphrey and Schmitz, 2002). However, in taking this step forward, the issue of collective efficiency was pushed to the background in the sense that it was not introduced in the new framework as an intermediate variable between global value chains and upgrading in industrial clusters. Hence, still little is known about how insertion into global value chains affects the prospects of gaining collective efficiency.

The purpose of this paper is to take a closer look at the case of the software cluster in Bangalore (India) from a collective efficiency perspective. Focusing mainly on the formative and initial phases of cluster development, it explores the theoretically derived hypothesis that the success of the cluster is effectively based on collective efficiency. It examines this hypothesis by asking what forms and degrees of collective efficiency prevail in the cluster. Has collective efficiency, defined as the competitive advantage 
derived from local external economies and joint action, been important for the development of the cluster? And which aspects of these two types of collective efficiency, external economies and joint action, have been central? Furthermore it asks how external linkages have impacted upon local relations. Has Bangalore's insertion into global value chains spurred or impeded collective efficiency in the cluster?

The software industry is an interesting case for examining the interplay between local and global dynamics. The production process for software is characterised by a high degree of technical divisibility, making the industry particularly amenable to 'fragmentation' (Lall et al., 2004) and hence global dispersion (Arora et al., 2001). At the same time software firms, as firms in other knowledge intensive sectors, tend to be clustered around specific cities and regions (Wibe and Narula, 2002; Heeks and Nicholson, 2002). It is clear, therefore, that strong forces of geographical dispersal as well as agglomeration coexist in the sector.

Several studies have examined Bangalore through different kinds of 'cluster lenses' (Balasubramanyam and Balasubramanyam, 2000; Dijk, 2003; Parthasarathy, 2004; Chaminade and Vang, 2008b). However, these studies have primarily been concerned with the issues of state policies and the origins of clustering rather than the role of clustering and collaboration for present day competitiveness. Similarly, the issue of external linkages has not been explicitly and systematically examined in these studies. ${ }^{1}$ Nevertheless, previous studies of Bangalore give some indications that collective efficiency is important in the IT cluster. Balasubramanyam and Balasubramanyam (2000, p.353), among others, argue that 'Marshallian-type scale economies or externalities are of profound significance for an explanation of the Bangalore cluster'. There are also indications that cooperative relations prevail. For instance, Fromhold-Eisebith (1999, pp.247, 254) found and that "some regional networking takes place that is reminiscent of the creative milieus or industrial districts identified in industrialised countries".

However, the hypothesis examined in this paper is also motivated the common notion that dense linkages and collaborative interaction between spatially agglomerated firms are particularly important determinants of success in knowledge-intensive sectors (Dunning, 2000; Saxenian, 1994). Moreover, the hypothesis is supported by a recent study examining the extent of collective efficiency in 40 Latin American clusters, trading in different sectors commodities. Among these, it was the specialised suppliers in software clusters were the ones benefiting the most from both local external economies and joint action (Giuliani et al., 2005; Pietrobelli and Rabellotti, 2004).

However, despite these expectations to the contrary, the paper reaches the counter intuitive conclusion that the success of firms in Bangalore is based primarily on 'individual' rather than 'collective' efficiency. The evidence of collective efficiency in Bangalore is limited and uneven; overall this factor has been relatively unimportant for the formation and growth of the cluster. Particularly, cooperative joint action is limited with regard to 'mission critical' tasks and does not materialise on a firm-to-firm basis. Moreover the increased specialisation and inter-firm division of labour inherent in the notion of local external economies is very limited. External linkages to world market actors and the broader issue of Bangalore's position in the international division of labour are important features in explaining these findings. In general external linkages, i.e., insertion into particular global value chains, have had a restraining effect on local linkage formation.

The paper is structured as follows. The next section elaborates the collective efficiency concept and discusses some of the developments in the literature. A backdrop 
for the empirical analysis follows in section three, giving a short account of the performance and economic structure of the cluster. The paper then turns to directly the issue of collective efficiency in Bangalore; section four discusses the role of local external economies, while section five explores the degree and type of joint action in intra-cluster linkages. The last section concludes by summarising the arguments, discusses the role of external linkages in more detail and proposes issues for further research.

\section{Collective efficiency and external linkages}

Research on export oriented clusters has been centrally concerned the respective roles of local and global sources of impetus for cluster formation for upgrading (Dana and Winstone, 2008). Insertion in global value chain provide an efficient means for initiation and upgrading a cluster but several studies have shown that more locally embedded processes are equally or more important for upgrading. Collective efficiency is defined as the competitive advantage of clustering, deriving from local external economies and joint action' [Schmitz, (1995), p.529]. The first element may be said to be 'passive' and the second 'active'. According to Giuliani et al. (2005), external economies and joint action, carry four defining characteristics each:

- Local external economies are the passive benefits that arise from geographical proximity of producers. They are the external gains that firms may derive from their location in a cluster. The defining characteristics are:

a the creation of a specialised and skilled labour pool

b the creation of a market for specialised inputs

c easy access to specialised knowledge on technologies and markets as well as the rapid dissemination of information

d improved local market access.

The concept of local external economies is restricted to incidental and unplanned gains and losses deriving from the co-location of firms; they are side effects of the activity of one firm on other firms in the cluster [Schmitz, (1999a), p.468].

- Joint action is the active element of collective efficiency and refers to joint collaborative efforts of improving effectiveness and competitiveness within the cluster. This can take form within vertical linkages:

a backwards to suppliers and subcontractors

b forward to traders and buyers.

Joint action may also occur within horizontal linkages:

c bilaterally between two or more local producers cooperating with regard to joint marketing of products, order sharing, shared used of specialised equipment, joint product development and exchange of know-how

d within multilateral linkages among a large number of local producers, particularly through cluster wide institutions, including business associations. 
By distinguishing between these two aspects of collective efficiency, two central propositions have been were forwarded in the literature:

- Cluster development arises from the combination of local external economies and joint action (Maskell and Malmberg, 2007; Dana and Winstone, 2008; Dana et al., 2013).

- In the long run, a shift in gear from passive to active collective efficiency is required for clusters to be competitive against increasing external competition (Chaminade and Vang, 2008a).

Thus, "Marshallian external economies are not sufficient to explain cluster development in developing countries. In addition to incidental external economies, there is often a deliberate force at work namely the conscious pursuit of joint action" [Schmitz, (1999a), p.1504; Parrilli, 2009]. Once a cluster is firmly established, and to the degree that it is outward oriented, the importance of passive efficiency decreases whereas active collective efficiency increases: "relying on the incidental economies of agglomeration is not sufficient, consciously pursued joint action is required" [Schmitz, (1999b), p.1644]. Therefore it is joint action that has been at the forefront of collective efficiency research.

\subsection{Internal sources of varied joint action outcomes}

As mentioned, the collective efficiency literature is generally optimistic with regard to the development of joint action. According to Humphrey and Schmitz, non-market coordination of economic activities is 'strong' within clusters and is 'characterised by close inter-firms cooperation and active public and private institutions' (2002, Table 1). These findings reflect the findings in the initial industrial district literature analysing the fashion industry in Prato (Italy) (Becattini, 1990). At the same time it is acknowledged in the literature that joint action is not an automatic outcome of clustering (Vang and Asheim, 2006).

The 1999 special issue of World Development brought our understanding of joint action further in empirically investigating the particular forms it generally takes (Schmitz and Nadvi, 1999). In the clusters examined in that volume the following tendencies was extracted across the cases:

- Vertical cooperation, forward and backwards, (type $a$ and $b$ ) was found to be pronounced and increasing.

- Horizontal firm-to-firm cooperation (c) generally was low although it was on the rise, particularly with regard to the sharing of information.

- Mixed evidence was found with regard to multilateral cluster-wide forms of cooperation $(d)$. In some clusters trade associations had played critical roles whereas in others they played a low key role or had failed in more ambitious effort.

On this background, more attention has been paid to the local heterogeneity of clusters, in efforts to understand why active collective efficiency do or do not materialise along different dimensions. Meyer-Stamer $(2002,2003)$ has sought to point why joint action may not be an automatic consequence of clustering. With regard to biases towards non-cooperation between individual firms, vertically and horizontally, a history of rivalry between firms often means that the basic conditions for cooperation is absent. ${ }^{2}$ 
Day-to-day business behaviour therefore can be predominantly opportunistic as firms are desperate for sales [Meyer-Stamer, (2003), p.20]. Moreover, any individual suggestion regarding cooperation has to be closely assessed by local firms in order to make sure that benefits outweigh the costs. Any type of cooperation has transaction and opportunity costs, but often the biggest issue is the potential risks involved. Firms often fear the loss of critical knowledge to competitors for instance regarding technology, markets and particular customers. "Often, the benefits will be long term and hypothetical, whereas costs and risks are obvious and immediate" [Meyer-Stamer, (2003), p.21]. Hence there may be strong forces impeding cooperative ventures with competitors or potential competitors. The general literature on collaborative innovations has also added how the specificities of the institutional setting affect the inclination to collaborate.

Following this line of thought, high levels of vertical joint action, as identified by Scmitz and Nadvi (1999), may be explained by the fact that linkages along this dimension will often be based on concrete business transactions. Therefore the benefits of cooperation are obvious and immediate. Horizontally related firms, on the other hand, may perceive of each other primarily as competitors. Diversity in terms of size or export orientation may result in different interest within clusters that may, in turn, impede multilateral joint action.

\subsection{External sources of varied joint action outcomes}

In the collective efficiency literature "the external world is characterized as a market presenting competitive challenges that must be met through improved organization and effort within the cluster" [Giuliani, 2007; Humphrey and Schmitz, (2002), p.2019]; this resembles learning from exporting in the related regional innovation systems literature (Padilla-Perez et al., 2009). But some observations regarding how external linkages were related to collective efficiency have been noted. In the case of the footwear cluster in the Sinos Valley, Brazil, some of the leading enterprises "put their alliance with a powerful foreign buyer above local cooperation" [Schmitz, (1999b), p.1654]. In the case of the Mexican footwear cluster of Guadalajara, Rabellotti (1999, p.1778) found that US buyers helped with the identification of competent suppliers and therefore played an important role in organising local production and enhancing inter-firm relations. Giuliani (2007) in the case of Chilian wine clusters show that external knowledge inputs do not become distributed equally within the cluster. Comparing with Dana and Winstone (2008) it is also evident that international dimensions do not have to play an important role in the early phases (see also Hamilton and Dana, 2003, for an introduction to how liberalisation impacts SMEs). Hence, the indications of how external linkages impact upon collective efficiency formation was non-conclusive.

It has been pointed out by Gereffi $(1996$, pp.428, 433-434) that in the industrial cluster literature, there is no suggestion regarding how different industrial clusters, engaged in the production of different commodities, should vary. Chaminade and Vang (2008a) suggest that the variation is not sector but cluster specific (e.g., learning differences reflect the development of the particular cluster's life cycle). The implicit argument forwarded by Gereffi is therefore that prospects for collective efficiency will vary in clusters catering for different industries. This issue was taken up in the study by Giuliani et al. (2005) (see also Pietrobelli and Rabellotti, 2004). They found that collective efficiency systematically reached different levels in different groups of sectors 
and tended to follow different patterns, particularly with regard to joint action. This was the case in both the clusters that were export oriented and those catering primarily for the local market.

The global value chains literature increasingly adheres to the view that governance structures in these chains differ systematically along sectoral variations (Gereffi et al., 2005). It follows that the type(s) of global value chains that a cluster is inserted into may have a significant impact on local governance modes. As mentioned, Schmitz's (2004) recent edited volume brings global value chains to the forefront, but the issue collective efficiency has been somewhat deserted. The 'cluster' is still used as a unit of analysis, but the focus is on how different types of value chain 'governance' affect local prospects for upgrading. As mentioned above, the issue of how collective efficiency is related to chain governance has only been sporadically addressed.

\title{
3 Methodological considerations
}

The method used in the paper is inspired by Burawoy (1998) notion of the extended case study. In contrast to many other fields of social sciences cluster studies has maintained a balance between qualitative and quantitative studies. Yet, there has increasingly been a tendency to embrace a more positivist approach underneath the case studies, where disentangled reporting is replacing engaged reflections, and where rigour replaces relevancy. Borowoy's extended case study represents a valid alternative to this transformation as it places the reflective science at the centre of the research. In his words:

\begin{abstract}
"Premised upon our own participation in the world we study, reflexive science deploys multiple dialogues to reach explanations of empirical phenomena. Reflexive science starts out from dialogue, virtual or real, between observer and participants, embeds such dialogue within a second dialogue between local processes and extra-local forces that in turn can only be comprehended through a third, expanding dialogue of theory with itself. Objectivity is not measured by procedures that assure an accurate mapping of the world but by the growth of knowledge; that is, the imaginative and parsimonious reconstruction of theory to accommodate anomalies." $(1998$, p.5)
\end{abstract}

He continues by suggesting:

\begin{abstract}
"The extended case method applies reflexive science to ethnography in order to extract the general from the unique, to move from the 'micro' to the 'macro', and to connect the present to the past in anticipation of the future, all by building on preexisting theory." (p.5)
\end{abstract}

These principles have been used to let the theory structure the interviews. Yet they have not been used for theory testing but as a heuristic device for identifying relevant themes that can be explored by means of semi-structured interactions/interviews with informants, observations and return trips to Bangalore allowing for updating the knowledge.

The analysis is thus based on primary qualitative data combined with data from secondary sources as well as structured observations. In last three months of 2002, 55 in-depth interviews were conducted in Bangalore with firms and supporting institutions. In 2005, follow up interviews were made in five selected firms. Respondents were chosen based on availability and snow-ball sampling criteria. Both large and small firms as well as more and less technology-driven firms were included in the sample (the 
2005 companies were only better performing companies). The primary data-based analysis conducted here is snapshot of the range and quality of inter-firm relations in prevailing Bangalore during the time field work was conducted. ${ }^{3}$ In 2015 , a last trip to Bangalore was undertaken and the updating of the knowledge was done though interactions with local scholars.

Recent desktop observations and interactions with local scholars do not suggest that this has changed significantly although research on embedded software suggests an increased horizontal collaboration between Indian software companies and Taiwanese chips producers (Parthasarathy and Aoyama, 2006).

Our search for joint action, the main focus of our empirical work, has been guided by the various forms of cooperation identified in previous software industry studies. These forms of cooperation are shown in Table 1.

Table 1 Different types of joint action in the software industry

\begin{tabular}{lll}
\hline a $\begin{array}{l}\text { Forward vertical } \\
\text { linkages }\end{array}$ & $\begin{array}{l}\text { Collaboration between buyers and suppliers; alliances along the } \\
\text { value added chain, technology agreements }\end{array}$ \\
b $\begin{array}{l}\text { Backward vertical } \\
\text { linkages }\end{array}$ & $\begin{array}{l}\text { Collaborative subcontracting. } \\
\text { c } \begin{array}{l}\text { Horizontal bilateral } \\
\text { linkages }\end{array}\end{array}$ & $\begin{array}{l}\text { Joint bidding/sharing of orders; agreements on products } \\
\text { complementary; technology and RandD collaboration. }\end{array}$ \\
d $\begin{array}{l}\text { Horizontal } \\
\text { multilateral linkages }\end{array}$ & $\begin{array}{l}\text { Joint training of labour; joint promotion, market research; } \\
\text { collective catalogues of products; policy advocacy. }\end{array}$ \\
\hline
\end{tabular}

Source: Based on Petirobelli and Rabellotti (2004, Annex 5), Basant et al. (2001, Table 1) and Heeks and Nicholson (2002)

This is to say that data collection and subsequent analysis has been guided by these forms of corporation. Hence, the forms of joint action shown in the table will also functions as reference points for the discussions below. The interviews have always insured a high degree of construct validity and the different data sources have been triangulated.

\section{Performance and economic structure of the cluster}

India has long been considered a typical problem case in development studies (Dana, 2000) with its current population of more than 1.2 billion people where the majority at least until recently has had a living standard on par with African countries. Where other Asian countries embarked on a path of catching up India remained trapped in the bottom (Chaminade and Vang, 2008a). The political economy-literature attributed central parts of the problems to an inefficient state that where lack of autonomy prevented it to implement efficient industrialisation theories. Hence, the tiger economies experimented with path shifts between ISI-strategies and EOS-strategies to achieve a combination on infant industry protection and subsequent positive effects of competition to reduce the negative effects of the ISI-strategies (Wade, 2003). India maintained trapped in an ISI-strategy leading to low levels of productivity and industries characterised by non-productive rent seeking behaviour (Hulten and Srinivasan, 1999; Mathews, 2009).

The software cluster located in Bangalore - albeit not the only positive case (Mathews, 2009) - represents India's most successful development initiative. This was only to a very limited extent the function of efficient state policies (although it has 
initiated many entrepreneurial and SME programs (Dana, 2000) but a combined effect of liberalising the banking sectors (where IT companies could function as subcontractors), the so-called 'Bug 2000-problem' which spurred a significant amount of outsourcing to India, returnees bringing with them network, education and entrepreneurial spirit and paradoxically a positive effect of the ISI strategy (Indian entrepreneurs still mastered outdated programming languages needed for solving the 'Bug 2000-problem' (Chaminade and Vang, 2008a).

The IT development - epitomised by Bangalore software cluster - triggered a transformation of the Indian development model and due to mimicking of the IT model other high tech industries gradually started to emerge (e.g., the pharmaceutical industry). Yet, software development and IT-services maintain being among the most important economic pillars. Today the industry produces approximately $7.5 \%$ of GDP (2012-numbers; up from 1.2 in 1998), and is responsible for $25 \%$ of the export (2012-numbers; up from less than 5\% in 1998) (http://www.nasscomm.in). The cluster of firms in Bangalore caters for more than $40 \%$ of total software exports from the India (and it the largest IT cluster, followed by Hyderabad, Chennai, Delhi and Pune). It has shown fast growth from the beginning of the 1990s (Table 2). During the financial year 2004-2005 the cluster exported software worth $\$ 6.270$ billion, out of a total 12.0 billion all India exports.

Table 2 Number of firms and software exports dispatched from Bangalore

\begin{tabular}{lcc}
\hline Year & No. of companies & Exports (\$ million) \\
\hline $1991-92$ & 13 & 2 \\
$1992-93$ & 29 & 7 \\
$1993-94$ & 53 & 29 \\
$1994-95$ & 79 & 57 \\
$1995-96$ & 125 & 134 \\
$1996-97$ & 163 & 249 \\
$1997-98$ & 207 & 400 \\
$1998-99$ & 267 & 736 \\
$1999-00$ & 782 & 941 \\
$2000-01$ & 928 & 1.551 \\
$2001-02$ & 1.038 & 2.070 \\
$2002-03$ & 1.154 & 2.648 \\
$2003-04$ & 1.322 & $4.200^{*}$ \\
$2004-05$ & 1.520 & $6.270^{* *}$ \\
$2012-13$ & n.a & $13.333^{* * *}$ \\
\hline
\end{tabular}

Notes: *Rounded figure from Indian Express (2004).

**Figure from Financial Express (2005).

***Figure from The Indian Express (2014), downloaded 13 January 2015.

Source: STPI-B $(2004,2005)$ and KSDIT (2004)

Fast growth has attracted new firms to the cluster in a cumulative manner. In 1991-1992, mere 13 software companies were located in the city while this number had increased to 1154 in 2002-2003 and in 1.520 in 2004-2005. In general, the largest Indian owned 
firms, in terms of market value, are also the oldest firms in the cluster. But a large number of small locally owned firms have been entering the scene in recent years. Thus, the cluster has a top-heavy structure.

Over the turn of the millennium there has been a significant expansion of companies worth less than $\$ 2$ million. The majority of firms belong to this size bracket. At the other extreme there are only few big players with markets values of more than \$20 million. Only two firms - Infosys Technologies and Wipro Ltd. - are valued to be worth more than \$200 million ten years ago (2003-2004 numbers) today (2014) Infosys in estimated to have a value of $\$ 31.11$ billion.

Foreign equity-based firms, which are not been examined for the present paper, constitute around $15 \%$ of the firms in Bangalore (The Hindu, 2002a), but these cater for $41 \%$ of the software exports dispatched from Bangalore (2002-2003 figures from KSDIT, 2004). Hence, TNCs are well represented in the list of the most exporting firms in the cluster, although matched by locally owned firms.

In addition to its fast growth and impressive share of overall Indian exports, qualitative indicators also point to that Bangalore stands out. For instance, while only 55 software firms in the world had reached level five in 2002 of the Software Engineering Institute's (SEI) globally acknowledged quality certification, capability maturity model for software (CMM), 22 of these are located in Bangalore [Naidu, (2002), p.7]. ${ }^{4}$ However, a more qualitative assessment also points to a more nuanced picture of the achievements. The composition of all-Indian exports reveals that the revenues generated from high valued-added, design-intensive functions, 'packaged software' and 'consulting', constitute less than 5\% in total (NASSCOM, 2004c). The remaining 95\% consist of lower-value added, downstream services, primarily 'programming' (coding and testing).

In line with these observations, we have previously argued that the Indian industry is on a lucrative but still 'low road' in the sense that it is based primarily on customised service, while for instance software product development has been limited (Chaminade and Vang, 2008b). The industry has been fast in adapting to customer requirements, which has necessitated important organisational innovations, but these have generally been aimed strengthening India's existing position in the international division of labour (Lema, 2009).

\section{The role of local external economies}

What forms of collective efficiency prevail in Bangalore? Have they been crucial to the success of the cluster? This section seeks to identify and discuss the role of external economies in Bangalore centring on the four dimensions mentioned in section two.

\subsection{The creation of a specialised and skilled labour pool (a)}

The development of the labour market feeding in to the software industry in Bangalore can be traced back to the time of independence from British rule in 1947. A defence strategic decision was made in New Delhi to locate strategically sensitive industries well away from borders and coastlands. Therefore, public and semi-public investments were poured into Bangalore due to its strategic location (in the middle of the Indian peninsular) 
with regard to defence related priorities (Kumar, 2001). Among these were a number of public science institutions and state-owned engineering-intensive firms, producing and conducting RandD in the fields of military equipment, telecommunications, and machine tools, aerodynamics and aircraft technology. Bangalore was well suited for these investments because of the education and research institutions already established there during the period of British rule. Of particular importance in this regard, was the Indian Institute of Science (IISc) set up in Bangalore in 1909 [Heitzman, (2004), pp.226-229]. ${ }^{5}$

Since the 1970s, a larger number of educational institutions in Bangalore have produced technical and engineering graduates. Regional engineering colleges (RECs) are located in and around Bangalore, contributing to the human capital with different engineering degrees and diplomas. Karnataka State, in which Bangalore is the capital city, has 65 engineering colleges in total (KSDIT, 2004).

After the software clusters industry's take-off phase in the 1990's, a range of public and private institutions supporting and feeding into the sector has been established. Thus, a number of privately financed colleges also feed into the industry, most of which precedes the takeoff of the cluster. The success of the industry has also now attracted a large number of private institutions including the two majors, NIIT and APTECH, collectively believed to have $60 \%$ of the private Indian software training market.

State institutions like the Indian Institute of Information Technology (IIIT-B) have been established thereby further improving the educational sector in Bangalore. The creation of IIT-B reflects a considerable extent of institutional adaptation as the cluster has developed and hence has called for ever-more educated labour. For this end, the Karnataka State Department of Information Technology (KSDIT), in cooperation with the IT industry and educational institutions, established a Board for Information Technology Education Standards (BITES) aiming at fine-tuning human resource inputs to the industry. Interviews in Bangalore also showed that the industry interacts with education institution on bilateral bases. For instance some companies have established agreement with education institutions allowing the companies to make suggestions for the curriculum and have the possibility of influencing the capabilities of the candidates the companies hire.

The cluster in Bangalore, as the Indian software industry as a hole, may be viewed as by-product of early state policies (Patibandla et al., 2000). Moreover, it is commonly acknowledged that the role of the state has been significant in forming the labour market pertaining to the industry. However, for the present discussion it is necessary to distinguish between those activities of the state that has external economy effects and those which do not.

As emphasised by Kumar (2001) the presence of state-owned highly specialises producers - such as the Hindustan Aeronautics Limited, Bharat Electronics Limited, Indian Telephone Industries - provided a critical mass in different domains of engineering that the software industry was able to tap into. Such state-owned enterprises have functioned as a training ground for software engineers and have thus had considerable external economy effects. During the course of the clusters' development, the skill-base of local firms have developed from simple coding and testing to more advanced tasks, in effect deepening the collective pool of skills (which are diffused through the inter-firm mobility of labour as discussed further below).

However, the stock of human capital, i.e., the cheap and relatively specialised engineering labour pool, is the single most important factor behind the clusters impressive growth. The source of this pool is primarily the large volumes of output and 
the excellence of local engineering related educational institutions. ${ }^{6}$ Hence, an explanation of clustering 'can be found in the supply of engineering graduates' (Arora et al., 2004). The labour pool created by these institutions, as such, falls outside the category of external economies being the deliberate effect of state policies. The many institutions engaged in the educating of software professionals produce a large pool of qualified and by international standard relatively cheap software labour every year. In 1997 the wages of Indian programmers and software developers were as little as $6-32 \%$ of his or her US counterpart, and although relative wages have increased markedly over the last decade, the wages of Indian software professionals is still a major determinant of securing outsourcing orders. Therefore, while the labour market has external economy effects these intertwine with the more 'basic' issue of the states commitments to higher education and the factor cost advantages in global software markets this has brought with it.

The creation of a specialised labour market, or labour market pooling, refers to instances where the geographical concentration of firms in a particular field creates a base of specialised skills. Such dynamics have been important in Bangalore, increasing in significance as the cluster has developed, and has attracted software man-power from other Indian regions. But the main causality is the reverse of what is normally envisaged: in Bangalore it is the existing pool of specialised skills which has led to a concentration of software firms in the area, rather than the other way around.

\subsection{The creation of a market for specialised inputs (b)}

The discussion of labour coincides with the next factor, the availability of inputs. It is often highlighted that where enterprises cluster they can support more specialised local suppliers of inputs and services and develop inter-firm division of labour. However, unlike traditional industries, the software industry in India has little demand for extra-industry inputs beyond skilled labour. But hardware and effective communication infrastructure is also essential to the industry. ${ }^{7}$ Such infrastructure (satellite data links) may be perceived as inputs as it is an integrated part of the production process in the software export industry. This need can be solved privately or purchased as club goods. Traditional infrastructural needs in terms of roads, ports, etc. - which is often of poor quality in India - is of little importance in the production of software.

In this regard, a very concrete form of local external economies arose when Texas Instruments marked the take-off for the software export industry in Bangalore in 1985. The satellite link that was set up by Texas Instruments, with the purpose of communicating with the headquarters in Dallas, proved to have excess capacity, and therefore the line was shared with other software companies in Bangalore on a lease basis [Lateef, (1997), ch. 4]. However, the problem of satellite links was solved on a more permanent basis, allowing for large scale development of the industry, when the first Software Technology Parks of India (STPI) division was set up in Bangalore in 1991. This gave the industry a head start over other Indian cities by supplying the local export industry with reliable high-speed data links. ${ }^{8}$

This point underscores the limited extent of improved intermediate inputs stemming from unintentional agglomeration effects. The fact that the state is the primary provider of the inputs (labour and commutation equipment) to the industry contradicts with Marshallian notion of improved inputs through competition (on price, quality and 
service) and a deepened internal division of labour. The cluster has a very limited inter-firm division of labour as will be discussed further in Section 5 of the paper.

\subsection{Access to specialised knowledge (c)}

The issue of access to information is related to the argument that clustering facilitates unintended technological spillovers in the form of rapid diffusions of know-how and ideas. This is the most dominant form of external economies in the cluster and is closely associated with labour mobility in the cluster and the co-location of firms in technology parks.

As the software industry has grown rapidly, and as tasks now often demand skills that go well beyond programming, the market for experienced software professionals is highly competitive with one of the highest attrition rates in the world (Dataquest, 2002). As skilled people rotate between different firms information and know-how is also distributed. The diversity of applications has led to continues evolvement of programming languages and methods for software development. As argued by Vijayabaskar and Krishnaswami (2003) knowledge in these areas are critical to firms in the cluster, particularly in the context of the specialisation in low-end programming tasks in a very diverse range of services. Thus, unintentional information spillovers have emerged due to the inter-firm mobility of employees. However, these authors also highlight that it is the largest firms in the cluster that are able to pay the highest wages and which therefore benefit the most from knowledge spillovers; they also highlight that the employees with the highest skills are often pursue careers in the USA, resulting in an outward movement of high-end labour.

A second factor of knowledge exchange is related to the co-presence of firms in technology parks. In 1997, Karnataka State introduced India's first regional state IT-policy, among other things, emphasising the development and upgrading of the industrial park, electronic city (Government of Karnataka, 1997). Karnataka State also owns a large share of the other important industrial park, International Tech Park Limited (ITPL) inaugurated in 2000. In a joint project between India, Singapore and private companies the ITPL delivers important services for software companies in relation to power, water supply, sewerage, telephones and data links. As a large number of firms are located in these technology parks they also function as a basis for face-to-face contact between firms and people in the industry.

A third externality which we may mention under this heading is the demonstration effect provided by the pioneers in the industry. As indicated by several interviewees, the successful business models of pioneering firms such as Infosys and Wipro could be readily copied by start-ups to their benefit.

\subsection{Local market access (d)}

The availability of inputs, discussed above, may be viewed as the external economies related to backward linkages in the inter-firm division of labour in the cluster. The issue of local market access, on the other hand, may be viewed as the external economies that may arise from forward linkages.

This is the least developed aspect of external economies in Bangalore. There is no data available on the share of domestic sales of Bangalore-based firms. However, all-India data suggests that despite a continuous expansion of the domestic market, 
software export earnings represent the bulk of the revenues from software production. Representing 79\% of total earnings (NASSCOM, 2004b), software exports have grown significantly. The domestic share of total software production, on the other hand, is shrinking in relative size. The local market is strained by a higher level of software piracy, downward pressure on prices, and a general "lower level of sophistication in IT spending for most Indian companies" (NASSCOM, 2004b). As seen above, firms have benefited from the local labour pool and the infrastructure to support export activity. Hence, Bangalore-based firms have agglomerated and benefit primarily because of the availability of inputs (labour) and the favourable conditions provided by the state, whereas outputs are mostly sold in distant markets and has played little role in this regard.

\subsection{Passive collective efficiency - concluding summary}

It can be hard to distinguish between factors that support cluster formation and those that support cluster growth once it is established. But many of the issues discussed in this section are primarily reasons behind initial cluster formation, rather than externalities, stemming from the activity of software firms in the region. The existence of local external economies as a crucial factor of success in Bangalore is not evident, at least when viewed from the perspective adopted here. Some factors related to passive collective efficiency have been identified. These have arisen with the emergence of a critical mass of firms within the industry, benefiting from early public sector investments, and include further labour market pooling and information spillovers. However local market access is the least developed aspect of external economies in the cluster. This is one reason that local firms benefit primarily from factors such as easy access to (some types of) information, rather than those that arise from direct transaction between firms, such as a deepened divisor of labour. Information spillovers, particularly through the inter-firm mobility of labour, have played some role. The findings are summarised in Table 3 .

Table 3 Local external economies

\begin{tabular}{lll}
\hline a & $\begin{array}{l}\text { Specialised } \\
\text { labour market }\end{array}$ & $\begin{array}{l}\text { Some labour pooling from other regions and establishment of private } \\
\text { educational institutions after industry 'take off'. Such effects are limed, } \\
\text { however, compared to the supply of engineering graduates resulting } \\
\text { from deliberate state polices. }\end{array}$ \\
b & $\begin{array}{l}\text { Improved } \\
\text { availability of } \\
\text { inputs }\end{array}$ & $\begin{array}{l}\text { Limited need for intermediate inputs (beyond skilled labour) in the } \\
\text { industry. Hardware purchased from distant markets and } \\
\text { communications infrastructure provided by the state. }\end{array}$ \\
Easy access to & $\begin{array}{l}\text { Relatively easy access to information through the rotation of skilled } \\
\text { software professionals; high degree of imitation of established firms } \\
\text { information }\end{array}$ \\
& $\begin{array}{l}\text { with regard to firm organisation and business models. Basis for } \\
\text { face-to-face interaction through the presence of well-developed } \\
\text { industrial parks. }\end{array}$ \\
& $\begin{array}{l}\text { Limited domestic market because of limited presence of local } \\
\text { technology-driven firms. Limited inter-firm division of labour. Some } \\
\text { reputation effect of the 'Bangalore Brand' although not related to the } \\
\text { local market. }\end{array}$ \\
& access
\end{tabular}


Considering the emphasis given to such economies in much of the literature on growth of the city, the evidence of their existence is limited. The growth of the cluster growth has been cumulative and self-reinforcing but to capture this we needs to consider additional factors than the four external economies discussed above. If we broaden the perspective, a more diffuse type of spillover should be considered which relates to the 'hype' surrounding Bangalore. Thus, an important type of spillover has, in fact, arisen as the city has increasingly gained a certain 'brand' name in overseas markets to the benefit of firms located in the city (Arora et al., 2004). It has attracted the attention of foreign (mainly the USA) players, increasingly becoming aware of offshore outsourcing from the city.

Bangalore was 'lucky' to be the first software cluster in India as the city 'incidentally' had that the right availability of skills at the right time (as a by-product of other activities), a relatively good system of infrastructure and a pleasant climate. This gave the cluster a certain first mover advantage to the benefit of its resident firms and created increasing external demand for services from firms located there.

Moreover, domestic policy makers, both federal - and at the regional state level, have been improving business conditions for software firms as the sectors potential was acknowledged. In explaining the basis of success in the cluster, the factors discussed here as external economies this factor should be interpreted in combination with the favourable factor costs and the 'business friendly' conditions deliberately provided by for this sector in the post-reform period by the national and regional state.

\section{The role of joint action}

The next subsections discuss the role of joint action as envisaged by the collective efficiency theory. To recapitulate, such joint action may occur within vertical linkages or within horizontal linkages. Within the former we distinguish between forward and backward linkages, within the latter we distinguish between bilateral and multilateral linkages.

\subsection{Forward vertical linkages (a)}

As seen in the previous section, local market access was the least prevalent feature of external economies in Bangalore. The local industry is heavily export dependent and generally outward oriented. Exports are carried out as outsourcing arrangements with OECD-based technology and consulting firms. Indian firms, on the other hand, specialise in providing complementary services vis-à-vis their foreign customers, functioning as 'virtual extensions' of OECD-based lead-firms (Lema, 2009). Very few firms in Bangalore specialise in packaged software in which the potential of alliances with customers and end-users within the cluster arguably are higher (Dossani and Kenney, 2002). Therefore forward linkages to foreign customers are well-developed whereas, generally, forward linkages internal to the cluster are rare. However, Indian firms are increasingly turning to their attention to the domestic market. Indian user industries are beginning to follow the global outsourcing trend, whereas software requirements have traditionally been dealt with in-house. Currently, the banking and financial industry is the largest local segment, but other segments may be waiting in line (NASSCOM, 2004a). Nevertheless, forward linkages to traders and buyers internal to the cluster are limited. 


\subsection{Backward vertical linkages (b)}

Turning to backward linkages, firms in Bangalore are often vertically integrated undertaking all tasks in-house. Activities, from the lowest-end tasks and upwards to the point that firms have reached within the value chain, tend to be undertaken within the same organisation. There are two primary reasons for limited subcontracting. The first is low barriers to entry into the industry combined with weak appropriability, i.e., an ease of imitating existing firms' processes and business models (Arora et al., 2004). Firms try to target different business domains, e.g., telecom, life sciences, financial services etc (known in the industry as vertical segments). However, such domain areas of focus present relatively weak differentiation markers as the downstream processes that Indian firms cater for, essentially coding and testing, are similar. Competitors can put together teams that can address different segments relatively easy. Local firms therefore fear the theft of customers. All respondents either mentioned this limited differentiation in business models and resulting narrow source of competitiveness as a main reason behind the low degree of joint coordination of activities, or acknowledged it when asked.

The second reason for vertical integration is due to restrictions set by customer firms. Customers are often afraid of information leakage and fear the loss of intellectual property or end-user data. Therefore local firms are under pressure to secure information that is property of customer firms or end users. Clauses on third-party involvement are therefore often built into the outsourcing arrangements specifying that work have to be kept in-house. 'Maintenance of secrecy' clauses naturally reduce the propensity to create cluster-internal linkages and joint action along the vertical dimension (Vijayabaskar and Krishnaswami, 2003). Often contracts are made between foreign TNC and specific units of the local firms. In the industry such software units that 'operate like the customer's own software services units' are known as dedicated ODCs, offshore development centres. Firms earmark an isolated part of the company's premises and a team of employees to the customer as to protect the intellectual property of the customer firm.

One example of this is a relationship between on of Bangalore's leading firm and a North American company that is world leader in telecommunication and networking products. This relationship has developed from a project-to-project type relationship with negligible information sharing into a repeat business relationship that include markedly information sharing as the Indian firm has full access to parts of the company's intranet, related to the specific project. The relation is based on tight legal contracts regarding the concealments of information. The reason for clients being cautious is the fear of competitors gaining access to sensitive information on products or customers, or that the Indian firms' employees would misuse the information. To ease the potential concern on behalf of investors, the Indian firm functions as a 'secret' partner to ensure a low-profile relationship. The ODC manager suggested that some client-firms would like to have a close but low-profile relationship, since they expected to loose brand value if it was known that large parts of their products were being developed by an Indian firm.

If firms face difficulties in ramping up staff-supplementation companies are therefore generally utilised rather than traditional subcontractors. Managers of leading firms stated that they had a 'considerable amount' of outsourcing to the smaller firms. The crucial issue for these firms the scale up and down fast in bottleneck periods. As noted by a leading Infosys representative, 'in a few areas we are outsourcing the whole project, but probably $70 \%$ of the outsourced work is staff supplementation'. Labour from such staff-supplementation companies are brought on to the premises of another firm to do 
simpler coding or testing work when supply side bottlenecks occur, thus these are used when the companies are under-staffed for shorter periods of time, most often in relation to specific projects. In these cases joint action with suppliers is negligible. Sub-contracting firms conduct low end work, often in the form of software testing and they most often work on isolated parts of the projects through one-way coordination modes, with tight specifications provided by the sourcing firm.

\subsection{Horizontal bilateral linkages (c)}

Horizontal bilateral linkages are generally not well developed in the cluster, with rivalry prevailing over cooperation. The existences of many firms with the same set of skills result in fierce competition reinforced by the absence of institutional mechanisms coordinating bids for projects or, for that matter, any other social institutions that bind the firms together [Vijayabaskar and Krishnaswami, (2003), p.187]. Neighbouring firms bid for the same projects and therefore and tend to think of inter-firm linkages in zero-sum terms. When projects are floated on the market, local firms engage in a competitive bidding race, arguably with result that prices are pushed down and the rents towards the customer (Arora et al., 2004). As already mentioned, competition for customers is also reinforced by competition for skilled personnel. As the software industry has grown rapidly, and as tasks now often demand skills that go well beyond programming, the market for experienced software professionals is highly competitive with one of the highest attrition rates in the world. ${ }^{9}$ Respondents argued that 'when it comes down to business we are all competitors' and used expressions such as 'cut-throat' when asked about the relations of competition vis-à-vis cooperation among firms in Bangalore.

This relates to the potential costs of engaging in new collaborative business activities, as seen from the perspective of large and well-established companies. While many of the smaller firms in the cluster needs market access and other resources in order to grow and generate revenue, the larger and well-established firms that have such resources are not prone to engage in local alliances. Representatives of smaller firms, particularly the ones specialising in higher end-niches complained that larger firms with market access and other kinds of resources did not want to engage in alliances despite attractive proposals. As an example, one smaller firm developed a product which was sold in Japan. In efforts to expand to other OECD markets the CEO sought to enter an alliance with a large company which could utilise its marketing channels in return for a percentage of revenues. However, the offer was turned down since the foreseeable revenues from this arrangement were marginal compared to the revenues from the main business lines and because it would 'blur' the business model of the large firm. Such an alliance could represent a big increase in revenues for the small firms but would only make a very marginal contribution to the revenues of the large firm.

Cooperation seems to take form more often between the two largest firms in the cluster. An avenue that seems promising is joint bidding for shared orders. Through this method, Wipro and Tata Consultancy Services jointly won a $\$ 70$ million per year Software development contract that was too large to undertake for either one of them, floated by the global investment bank, Lehman Brothers. ${ }^{10}$ This consortium may serve as a role model of horizontal collaboration for the industry in Bangalore. Besides the demonstration effect of such arrangements, collaboration also means that Indian firms are able to undertake larger project vis-à-vis their domestic and overseas competitors. 
Similarly Wipro and Infosys broke new ground by collaborating on a project for the local Union Bank in 2002. These firms have recently teamed up engaging in a joint project on installing the banking system Finacle in Union Bank. The product is Infosys' only product, and Wipro, a conglomerate which diversified from hardware into software, will be maintaining and installing the product in addition to providing the required hardware. As the creator of Infosys, Naryana Murthy, stated: "we have come together in a spirit of co-opetition (collaborative competition)" (Business Standard, 2002). ${ }^{11}$ Wipro also tied up with the midsized Geometric Software to sell their services jointly. Geometric was seen to have expertise in engineering and design software, an area in which Wipro is weaker. However, the arrangement did not go far due to fear of cannibalisation. The managing director of Geometric stated that "maybe we were ahead of the times, maybe it is not possible for partnership to be successful among two software services companies" (in Rajawat, 2004).

As these examples indicate, cooperation has been more prone to materialise between large firms in the cluster. Furthermore it seems that the domestic market provides better opportunities for cooperation between domestic firms than does the export market and in such cases may include technology cooperation, such as integrating Infosys software with Wipro systems and hardware. Smaller firms may benefit from collaboration, even in relation to the export market, but our evidence suggest that this is only the case in 'softer' areas such information sharing.

However, interviews indicated that firms benefited from such access to information in the start-phase in particular. As an illustrative example, Tarang a local Wipro offspring started in 2000, targeting the banking segment. During the phase of establishment, networking with previous Wipro colleagues, who had started on their own, was important. For instance, they got useful advice in terms of how to contact a venture capital firm, how to organise the new firm and how to select employees. Also during this phase Tarang was helped by Dawn Consulting (itself a Wipro offspring) in establishing contacts. But interviews also indicated that in terms of everyday business, information was kept much tighter, partly due to restriction set by customer firms.

But foreign firms also impact on local linkage formation more directly. An illustration of how such linkages restrain cooperative relations is the relationship between a group of local firms - Tata Consultancy Services, Wipro, Infosys, and Sasken - and their client Nortel, a leading Canadian telecommunication firm, specialising in network technology. Despite all four Indian firms working for the same client, the outsourcing relationship is organised in such a way that interaction and collaboration between the Indian firms is not required. Each Indian firm is associated with independent sub-projects and Nortel alone is responsible for the integration. Hence, the local firms in the 'Nortel network' do not work together on projects. There are some limited interaction related to the standards adopted by Nortel but do not extend to joint RandD or other form of functional collaboration. The organisation of the outsourcing arrangement, then, limits the opportunities for collectively building additional competencies in respect to Nortel, as well as in general [see also Basant et al., (2001), p.8f].

\subsection{Horizontal multilateral linkages (d)}

Multilateral joint action is the most widespread aspect of collective efficiency. Hence, the most prevalent form of interaction between firms is within industry 'meta structures' such 
as business associations. However, as with other forms of collective efficiency identified, these are not strictly localised. Below we discuss the three most influential cases of such multilateral joint efforts of improving competitiveness of the software industry. These are all Bangalore branches of wider organisations.

\subsubsection{NASSCOM}

The all-Indian National Association of Software and Service Companies is the most significant apex body related to the industry. The combined revenue of NASSCOM member companies constitutes almost $95 \%$ of the revenue of the software industry in India.

Efforts of improving conditions for member firms have traditionally taken two forms.

Firstly, it has been able to establish close linkages to central state institutions through this membership strength. As a lobbying body NASSCOM has had markedly influence on the content of polices related to the software industry. Secondly, it has promoted the Indian software industry in existing and upcoming foreign markets. By organising trade fairs and promoting the industry in general, NASSCOM is performing an important job for the industry as an 'advertising agency' for the industry. Recently, NASSCOM has hired local public relations agencies to handle the promotion of the Indian software industry in the US and UK markets. The aim is to establish and reinforce Indian software brand where: 'India is a quality mark, just as Japan is for electronics' (interview with NASSCOM representative).

However, these functions of NASSCOM are arguably more important to the Indian software industry as group rather than to the individual firm. For example one of the firms interviewed chose to discontinue its membership of NASSCOM with reference to reducing expenses when the company was under pressure from decreasing revenues. Had the NASSCOM membership delivered substantial assistance in procuring business or mission critical information it seems unlikely that this firm would have discontinued the membership.

NASSCOM has not traditionally delivered support related to industry-enhancing functions such as training, industrial consultancy or innovation support. This contrasts with pro-active associations undertaking skill improvement, standard setting, and competition regulation in efforts to move towards 'upgrade driven' competition (cf. Nadvi, 1999; Doner and Schneider, 2000).

However, since 2002 NASSCOM has begun to take a more active role in establishing more hands-on, industry-improving initiatives in three different areas. Firstly, NASSCOM has set a new course towards nurturing the SME especially in relation to marketing problems within the segment, in acknowledgement of the longer-term importance of SMEs. Second, NASSCOM has increased its focus on product development companies. It has established a product development special interest group in addition to its existing. ${ }^{12}$ Third, it has now taken on a more regional focus. During 2002, NASSCOM has established a regional office in Bangalore. It seeks now to promote information sharing and close cooperation between NASSCOM and KSDIT and STPI-B and promote inter-firm collaboration through the 'Bangalore SME forum'. Thus it has now adopted a more regionally oriented focus and indeed has a stated mission of identifying avenues for cooperation among local firms, e.g., subcontracting from TNCs in with operations in India to local SMEs (interviews). 


\subsubsection{The IndUS Entrepreneurs, Bangalore (TiE-B)}

TiE was formed in 1992 by South Indians in Silicon Valley as an association aimed at fostering entrepreneurship within the South Asian community by channelling mentorship and resources. Today there are TiE chapters in several Indian and US cities, and recently also in Canada, UK and Pakistan, forming a transnational network of entrepreneurs. TiE is a non-profit organisation that seeks to create a platform for entrepreneurs and investors to meet. Originally, the organisation's efforts were focused at establishing contact between US-based business angels and Indian entrepreneurs, but today the organisation also focuses at intra-Indian investors and entrepreneurs. Furthermore, the organisation aims at being a forum for networking between the members through a number of activities sponsored by TiE, including monthly meetings with speaker presentations, networking meetings, company forums and the annual conference TiEcon (TiE, 2004).

The first Indian TiE-chapter, and the most active in India, is the Bangalore chapter, established in 1998 and 2003 had 170 member firms out of a total of 1,154. The basic charter of TiE-B is creating networking among its members and to link the Bangalore-based network with the global TiE network. Thus, a function of TiE-B is to channel financial resources from the US to India through venture capital and angel investment.

\subsubsection{Software Process Improvement Network (SPIN)}

The Software Process Improvement Network (SPIN) is a global non-profit and decentralised organisation, which focuses on providing a forum for discussion of ideas on software process improvement, which would benefit all participating organisations. SPIN as a concept is developed by the Carnegie Mellon Institute and associated to the SEI-CMM standard. The Bangalore branch (SPIN-B) was founded in 1991/1992, based on its predecessor the Software Quality Group, as these people became more and more involved in the SEI-CMM standard. With 900 members, SPIN-B is considered the second largest SPIN chapters in the world (after the Chicago chapter) and is hosted by the STPI-B. The primary function of SPIN is to have a monthly meeting open to all SPIN-members, with a talk given by one of its members. In addition, there are special interest groups such as the project management group and the benchmarking group.

According members of the coordinating body of SPIN-B, the network prepares the industry for the 'next generation team', which are cross-organisational teams involving competitors and clients and hence is it significant in terms of influencing the directions that the software industry might take. This group is now sharing second-process data (filtered for critical information) which is in itself seen as a breakthrough in terms of collaboration. As one informant said, "Seven years ago we couldn't have formed the Benchmarking Group, but today this is happening". The key point to emphasise here is that normally firms are very reluctant to share any form of information related to actual business processes and current activities.

\subsection{Active collective efficiency - concluding summary}

Active collective efficiency is less prevalent than its passive counterparty (see Table 4). 
Table 4 Joint action

\begin{tabular}{|c|c|c|}
\hline $\mathrm{a}$ & $\begin{array}{l}\text { Backward } \\
\text { vertical } \\
\text { linkages }\end{array}$ & $\begin{array}{l}\text { Backward linkages to local firms are very limited; inputs consist of labour } \\
\text { or foreign produced hardware. Subcontracting also limited - takes the form } \\
\text { of in-house staff supplementation; little differentiation in production lines; } \\
\text { narrow source of competitive advantage; intense rivalry. }\end{array}$ \\
\hline b & $\begin{array}{l}\text { Forward } \\
\text { vertical } \\
\text { linkages }\end{array}$ & $\begin{array}{l}\text { The industry is primarily based on based on outsourcing deals with foreign } \\
\text { customers. Forward linkages are therefore primarily external to the cluster, } \\
\text { whereas cluster-internal linkages are few and weak. High dependence on } \\
\text { foreign clients; local industrial organisation governed by foreign firms; } \\
\text { clauses on information sharing. }\end{array}$ \\
\hline $\mathrm{c}$ & $\begin{array}{l}\text { Horizontal } \\
\text { bilateral } \\
\text { linkages }\end{array}$ & $\begin{array}{l}\text { Limited firm-to-firm linkages. Networking important during the start-up } \\
\text { phase of new ventures but unimportant in terms of day-to-day business. } \\
\text { Technological cooperation is absent to low. No functional collaboration } \\
\text { between cluster-based firms. }\end{array}$ \\
\hline $\mathrm{d}$ & $\begin{array}{l}\text { Horizontal } \\
\text { multilateral } \\
\text { linkages }\end{array}$ & $\begin{array}{l}\text { There are very strong business associations. These collect and distribute } \\
\text { information, promote good corporate governance, promote international } \\
\text { standards and deploy marketing initiatives. Until recently, no strategies for } \\
\text { specialisation. Recent upgrading initiative promoting software products and } \\
\text { collaboration between SME's. Information sharing networks related to } \\
\text { technical and managerial matters Local institutions for global integration; } \\
\text { local 'branches' of US-based institutions (TiE and SPIN). }\end{array}$ \\
\hline
\end{tabular}

A strong (national) business association is effective in lobbying with the central government and marketing abroad and has been significant in this regard. It has generally maintained a hands-off approach, however, to collaboration and interaction among its members and between members, although such initiatives have been launched recently. There are well-institutionalised information sharing forums related to global industry standards and business-development discussion forums. However, both vertical and horizontal interaction related to core business areas lies beyond the scope of firm-to-firm cooperation and other group efforts.

In general, joint action is limited by the low degree of vertical linkages in the cluster. In the cases that subcontracting occurs, it is limited to the provision of specific task with given prescriptions. Hence backward linkages rarely extend beyond limited complexity and can hardly be described as collaborative. Forward linkages internal to the cluster carry a higher potential but such linkages are rare. Thus a central feature of the software cluster in Bangalore is that firms are not linked by input-output relations to any significant degree.

Horizontal cooperative relations are also limited. We have not been able to identify, e.g., research consortia among local firms, the use of common components in the software production, nor are there cases of joint RandD or joint product development. The industrial structure of local firms does not allow for symbiotic cooperation, based on mutual differentiation, to any significant degree. The relatively narrow source of competitive advantage leaves little scope for 'deep' specialisation, which, in turn, means that the possibilities for building alliances based on complementary competencies are limited. Even if product-oriented firms can offer complementary capabilities linkages do not develop as the potential earnings from lignin up are generally considered too low a return on investment. Therefore there is little interaction between firms, let alone cooperation in the 'collective efficiency sense', i.e., joint action to improve growth and development for alliances of firms. The multilateral bodies discussed above are now becoming more aggressive terms of facilitating local cooperation and upgrading efforts, 
but has traditionally played more marginal roles in this regard. However, these initiatives are cumulative effects of the clusters success rather than its root causes.

\section{Conclusions}

Informed by the literature on clusters in developing countries, this paper examined the role of collective efficiency in cluster formation and take-off. It started from the notion of positive externalities as emphasised by Alfred Marshall. These became known as the 'passive' element of collective efficiency. In contrast, 'active' collective efficiency was based on deliberate vertical and horizontal collaboration between cluster-based firms. The paper found that active collective efficiency played only a limited role in the success of the cluster, but many of the expected externalities prevail. External economies work to the benefit of firms located in the cluster, even if collaborative relations are not deep or widespread. The remainder of the paper unfolds these conclusions and discusses how cluster organisation was influenced by the insertion in global value chains.

\subsection{Bangalore and collective efficiency theory}

Collective efficiency theory put forth two major propositions. The first was that cluster development is based on the combination of passive and active collective efficiency. The second was that in the face of international competitive pressures mature cluster had to switch gears towards increased reliance in active collective efficiency.

The dissection of collective efficiency into different elements has allowed for a more nuanced discussion of the aspects of collective efficiency that worked to advance growth and competitiveness. It is clear from the preceding discussion that distinguishing between active and passive collective efficiency is not enough. In relation to the first proposition, we have been able to specify what aspects that have contributed to the formation and success of the cluster in Bangalore. Whereas the findings sustain the importance of public and private institutions it questions the importance of local firm-to-firm cooperation in clusters. Cluster development in Bangalore is based on the efficiency of individual firms, rather than on 'collective efficiency' as such. While joint action related to core business areas of the firms might seem viable from a theoretical point of view, they do not conform to the logic of business as seen from the perspective of the local firm.

Moreover, the findings point out that the specific type of local external economies at play, on the one hand, and the prospects for joint action, on the other, are interrelated. Most importantly the fact that firms had limited local market sales is important in the limited differentiation and hence cooperation among cluster-based firms. As service-suppliers for the global market, Bangalore-based firms thrived on a relatively narrow source of competitive advantage in downstream tasks that left little scope for specialisation. In general, firms had similar offerings and catered for the same nodes in the production chain. The comparison with software clusters in Mexico and by Brazil included in the study by Pietrobelli and Rabellotti (2004, pp.39-43, pp.89-92) is revealing in this regard. These clusters are characterised by 'medium to high' degrees of local market access which means that forward linkages are more integrated. Firm-to-firm cooperation is quite common in these clusters, spanning over technological collaboration and coordination of activities to meet customer's requirements. For instance many firms 
set up agreements with other firms to complement their software products in order to offer their customers full systems that satisfy their total needs. Proximity to the customers has been important in these cases. In Mexico, for instance, proximity to customers have provided opportunities of developing niches according to customers' needs, such as tourism applications in the south and software for the oil industry along the Pacific coast (2004, p.47).

In relation to the second hypotheses this paper has emphasised that although the cluster is markedly outward-oriented, it has succeed despite a limited degree of joint action. However, in the light of the discussion above, we may argue that what is required in the longer run is probably a shift towards one type of local external economies, namely a greater reliance on the local market. This may in turn broaden the scope for collaboration. Local market access maybe an important precondition for successful and more complex forms of joint action.

While the discussion of the two propositions above show how this case does not conform to the core 'vision' of the theory, there are also some points on which the Bangalore case aligns with recent insights of the literature. The first is that collective efficiency is not an automatic outcome of clustering and that there may often be important internal biases towards non-cooperation. While this point has already been touched upon above, we may explain the tendency towards 'non-cooperation' between local firms in the Bangalore cluster in terms of similar in competencies and skills and in terms of the non-aligned aspirations between the established and upcoming firms in the cluster. These observations are closely related to the issue discussed in the next subsection, namely that cluster-external relations may be of crucial importance in forming local relations.

\subsection{Global value chains and collective efficiency}

As mentioned there is no suggestion in the collective efficiency literature regarding how different clusters trading in different commodities with different type and degrees of technology and human capital should vary. Research linking different cluster's upgrading potentials to different types of value chain 'governance' (Schmitz, 2004) does not address the question of collective efficiency as an intermediate factor in this relation. However, when concerned with high-technology industries, a powerful proposition is that spatial proximity and local interaction are particularly important determinants of success. What the case of Bangalore adds to the collective efficiency debate is that even despite the alleged strong tendency toward localised networking in high-tech industries, local inter-firm arrangements in Bangalore are influenced by cluster-external business linkages. It is clear that the focus on internal linkages is insufficient and that, in this case, external linkages help to explain way why active collective efficiency did not develop further within the cluster.

The global value chains framework takes us along way in this specific case. In particular, work on modular value chains in the global economy (Gereffi et al., 2005; Sturgeon, 2002) emphasises that global trade is increasingly characterised by western lead firms that are deepening their core competences. Hence, they concentrate on specific tasks in the value chain while outsourcing or offshoring the aspects of production that can be codified. Typically, they undertake upstream functions and provide design-specifications, while downstream producers in low-cost areas provide most remaining functions in the production chain. The production process thus becomes 
modularised with distinct breaks between what could be called the lead firms' 'product-tasks' and the service providers' generic 'process-tasks'. The software industry in India was particularly prone to this form of organisations due to the low transportation cost and rather high degree of codification which facilitates the 'global' organisation of production. The most consolidated forums identified in Bangalore can be seen as joint action to develop mechanism for entering such modular production networks through the protocols of codification. ${ }^{13}$ Competitiveness has required the establishment of 'open systems', that ensures the flexibly of client firms. Our case suggests that competitiveness based on this mode of organisation inhibits the development of active collective efficiency. Furthermore, our analysis has shown that, customers are often afraid of information leakage. This often restrains the types of linkages that can be formed and reinforces the arms-length distance between local firms.

For many years there was a common consensus that the growth of the software industry in Bangalore was on a lucrative but still 'low road' to development [Chaminade and Vang, 2008a; Sridharan, (2003), p.27; D’Costa, 2003]. Recent research argues that the picture is now more complex with increasing innovation taking place (Lema, 2014) and interestingly this has seen a transformation to increasingly 'relational' global value chain linkages between firms in India and clients abroad (Lema, 2015). The question is whether or not these changing global value chain relationships influence the local organisation of the industry - and vice versa. Accordingly future research should examine the complex relationships between clusters and global value chains as they evolve, independently and in conjunction, towards increasingly innovation-intensive positions in the international division of labour.

\section{References}

Arora, A., Arunachalam, V.S., Asundi, J. and Fernandes, R. (2001) 'The Indian software industry', Research Policy, Vol. 30, No. 8, pp.1267-1287.

Arora, A., Gambardella, A. and Torrisi, S. (2004) 'In the footsteps of Silicon Valley? Indian and Irish software in the international division of labour', in Breshnahan, T. and Gambardella, A. (Eds.): Building High-Tech Clusters, pp.78-120, Cambridge University Press, Cambridge.

Audretsch, D.B. (2003) 'Innovation and spatial externalities', International Regional Science Review, Vol. 2, No. 26, pp.167-174.

Balasubramanyam, V.N. and Balasubramanyam, A. (2000) 'The software cluster in Bangalore', in Dunning, J.H. (Ed.): Regions, Globalization, and the Knowledge-Based Economy, Oxford University Press, Oxford and New York.

Basant, R., Chandra, P. and Mytelka, L.K. (2001) 'Inter-firm linkages and development of capabilities in the Indian telecom software sector', Economics Series No. 14, East-West Center, Honululu.

Becattini, G. (1990) 'The Marshallian industrial districts as a socio-economic notion', in Pyke, F. et al. (Eds.): Industrial Districts and Inter-Firm Co-Operation in Italy, pp.37-51, International Institute for Labour Studies, Geneva.

Burawoy, M. (1998) 'The extended case method', Sociological Theory, Vol. 16, No. 1, pp.4-33.

Business Standard (2002) 'Wipro, Infosys to pilot Union Bank's technology push', Business Standard, 11 June.

Chaminade, C. and Vang, J. (2008a) 'Upgrading in Asian clusters rethinking the importance of interactive learning', Science Technology and Society, Vol. 13, No. 1, pp.61-94. 
Chaminade, C. and Vang, J. (2008b) 'Globalisation of knowledge production and regional innovation policy: supporting specialized hubs in the Bangalore software industry', Research Policy, Vol. 37, No. 10, pp.1684-1696.

D'Costa, A. (2003) 'Uneven and combined development: understanding India's software exports', World Development, Vol. 31, No. 1, pp.211-226.

Dana, L.P. (2000) 'Creating entrepreneurs in India', Journal of Small Business Management, Vol. 38, No. 1, pp.86-91.

Dana, L., Granata, J., Lasch, F. and Carnaby, A. (2013) 'The evolution of co-opetition in the Waipara wine cluster of New Zealand', Wine Economics and Policy, Vol. 2, No. 1, pp.42-49.

Dana, L.P. and Winstone, K.E. (2008) 'Wine cluster formation in New Zealand: operation, evolution and impact', International Journal of Food Science and Technology, Vol. 43, No. 12, pp.2177-2190.

Dataquest (2002) 'A DQ-IDC India Survey: Indian it's best employers', 10 September.

Delgado, M., Porter, M.E. and Stern, S. (2015) 'Defining clusters of related industries', Journal of Economic Geography, pp.1-38, doi: 10.1093/jeg/lbv017 [online] http://joeg.oxfordjournals.org/content/early/2015/06/02/jeg.lbv017.full.pdf + html?sid=ba101af 3-7466-4e62-b838-8a9274ed4d7b (accessed 14 January 2016).

Dijk, M.P.v. (2003) 'Government policies with respect to an information technology cluster in Bangalore, India', European Journal of Development Research, Vol. 15, No. 2, pp.93-108.

Doner, R.F. and Schneider, B.R. (2000) 'Business associations and economic development: why some associations contribute more than others', Business and Politics, Vol. 2, No. 3, pp.261-288.

Dossani, R. and Kenney, M. (2002) 'Creating an environment for venture capital in India', World Development, Vol. 30, No. 2, pp.227-253.

Dunning, J.H. (2000) Regions, Globalization, and the Knowledge-Based Economy, Oxford University Press, Oxford.

Financial Express (2005) 'Karnataka posts 52\% growth in software exports in 2004-05', 29 April.

Fromhold-Eisebith, M. (1999) 'Bangalore - a network model of innovation-oriented regional development in NICs?', in Malecki, E.J. and Oinas, P. (Eds.)" Making Connections: Technological Learning and Regional Economic Change, pp.231-260, Ashgate, Aldershot, Hants.

Gebreeyesus, M. and Mohnen, P. (2013) 'Innovation performance and embeddedness in networks: evidence from the Ethiopian footwear cluster', World Development, Vol. 41, No. 1, pp.302-316, doi: 10.1016/j.worlddev.2012.05.029.

Gereffi, G. (1996) 'Global commodity chains: new forms of coordination and control among nations and firms in international industries', Competition and Change, Vol. 4, pp.427-439.

Gereffi, G., Humphrey, J. and Sturgeon, T. (2005) 'The governance of global value chains', Review of International Political Economy, Vol. 12, No. 1, pp.78-104.

Giuliani, E. (2007) 'The role of technological gatekeepers in the growth of industrial clusters: evidence from Chile', Regional Studies, Vol. 45, No. 10, pp.1329-1348.

Giuliani, E. and Morales, X.M. (2012) 'The cluster model: whether and what developing countries should learn from advanced countries', Int. J. Transitions and Innovation Systems, Vol. 2, Nos. 3-4, pp.219-232.

Giuliani, E., Gorgoni, S., Gunther, C. and Rabellotti, R. (2014) 'Emerging versus advanced country MNEs investing in Europe: a typology of subsidiary global-local connections', International Business Review, Vol. 23, No. 4, pp.680-691.

Giuliani, E., Maffioli, A., Pacheco, C., Pietrobelli, C. and Stucchi, R. (2013) Evaluating the Impact of Cluster Development Programs, IDB Publications 81539, Inter-American Development Bank, Washington DC.

Giuliani, E., Pietrobelli, C. and Rabellotti, R. (2005) 'Upgrading in global value chains: lessons from Latin American clusters', World Development, Vol. 33, No. 2, pp.549-573. 
Government of Karnataka (1997) Information Technology Policy of Karnataka 1997.

Gutiérrez-Martínez, I., Duhamel, F., Luna-Reyes, L.F., Picazo-Vela, S. and Huerta-Carvajal, M.I. (2015) 'The role of joint actions in the performance of IT clusters in Mexico', Competitiveness Review, Vol. 25, No. 2, pp.156-178, doi: 10.1108/CR-09-2013-0073.

Hamilton, R.T. and Dana, L.P. (2003) 'An increasing role for small business in New Zealand', Journal of Small Business Management, Vol. 41, No. 4, pp.402-408.

Heeks, R. and Nicholson, B. (2002) Software Export Success Factors and Strategies in Developing and Transitional Economies, Development Informatics Working Paper Series No. 12, Institute for Development Policy and Management, University of Manchester, Manchester.

Heitzman, J. (2004) Network City: Planning the Information Society in Bangalore, Oxford University Press, Oxford.

Hulten, C. and Srinivasan, S. (1999) Indian Manufacturing Industry: Elephant or Tiger? New Evidence on the Asian Miracle, Working Paper No. 7441, National Bureau of Economic Research.

Humphrey, J. (1995) 'Special issue on industrial organisation and manufacturing competitiveness in developing countries', World Development, Vol. 23, No. 1.

Humphrey, J. and Schmitz, H. (2002) 'How does insertion in global value chains affect upgrading in industrial clusters?', Regional Studies, Vol. 36, No. 9, pp.1017-1027.

Iammarino, S. and McCann, P. (2010) 'The relationship between multinational firms and innovative clusters', In Boschma, R. and Martin, R.L. (Eds.): The Handbook of Evolutionary Economic Geography, Elgar Original Reference, Edward Elgar Publishing, Cheltenham, UK, ISBN 9781847204912.

Iammarino, S., Odile, J.E.M. and McCann, P. (2009) 'Multinationals firms and technological innovation: the 'global versus local' challenge', in Farshchi, M.A., Janne, O.E.M. and McCann, P. (Eds.): Technological Change and Mature Industrial Regions: Firms, Knowledge and Policy, pp.29-43, New Horizons in Regional Science, Edward Elgar Publishing Limited, Gloucestershire, UK, ISBN 9781847200891.

Indian Express (2004) 'Karnataka IT exports touch USD 4 billion in 2003-04', 4 June.

Intarakumnerd, P. and Vang, J. (2006) 'Clusters and innovation systems in Asia', Science, Technology and Society, Vol. 11, No. 1, pp.1-7.

KSDIT (2004) It Scenario Karnataka, Department of IT and Biotechnology, Government of Karnataka [online] http://www.bangaloreit.com/html/itsckar/itindustriesothercities.htm (accessed 1 December).

Kumar, N. (2001) National Innovation Systems and the Indian Software Industry Development, Background paper for World Industrial Development Report (UNIDO).

Lall, S., Albaladejo, M. and Zhang, J. (2004) 'Mapping fragmentation: electronics and automobiles in East Asia and Latin America', Oxford Development Studies, Vol. 32, No. 2, pp.407-432.

Lateef, A. (1997) Linking up with the Global Economy: A Case Study of the Bangalore Software Industry, International Labour Organization (ILO), Geneva.

Lema, R. (2009) 'Bangalore's software cluster in the 1990s', in Kumar, R. and Patibandla, M. (Eds.): Institutional Dynamics and the Evolution of the Indian Economy, Palgrave Macmillan, Basingstoke.

Lema, R. (2014) 'Offshore outsourcing and innovation capabilities in the supply base: evidence from software firms in Bangalore', Journal International Journal of Technological Learning, Innovation and Development, Vol. 7, No. 1, pp.19-48, Inderscience.

Lema, R. (2015) 'Problem framing in new innovation spaces: insights from software outsourcing', In McKelvey, M. and Bagchi-Sen, S. (Eds.): Innovation Spaces in Asia: Entrepreneurs, Multinational Enterprises and Policy, Chapter 14, pp.279-300, Edward Elgar, Cheltenham, UK.

Maskell, P. and Malmberg, A. (2007) 'Myopia, knowledge development and cluster evolution', Journal of Economic Geography, Vol. 7, No. 5, pp.603-618. 
Mathews, J.A. (2009) 'China, India and Brazil', Asian Business and Management, Vol. 8, No. 3, pp.5-32.

Meyer-Stamer, J. (2002) 'Clustering and the creation of an innovation-oriented environment for industrial competitiveness: beware of overly optimistic expectations', International High-Level Seminar on Technological Innovation, February, United Nations University, Beijing, Conference paper.

Meyer-Stamer, J. (2003) 'Obstacles to cooperation in clusters and how to overcome them', Developing Alternatives, Vol. 9, No. 1.

Nadvi, K. (1999) Facing the New Competition: Business Associations in Developing Country Industrial Clusters, ILO, Geneva.

Naidu, B.V. (2002) Growth of the Indian Software Export Industry - Role of STPI, Software Technology Parks of India, Bangalore.

NASSCOM (2004a) India Domestic It Market'. National Association of Software and Services Companies [online] http://www.nasscom.org/artdisplay.asp?cat_id=410 (accessed 1 December).

NASSCOM (2004b) Indian Software and Services Industry: Nasscom Analysis (Indian It Industry Factsheet) [online] http://www.nasscom.org/download/IndianITIndustryFactsheet.pdf (accessed June 2005).

NASSCOM (2004c) It Software and Services Market, National Association of Software and Services Companies [online] http://www.nasscom.org/artdisplay.asp?cat_id=342 (accessed 1 December).

Padilla-Perez, R., Vang, J. and Chaminade, C. (2009) 'Regional innovation systems in developing countries: integrating micro and meso-level capabilities', in Lundvall, B-A., Vang, J., Joseph, K.J. and Chaminade, C. (Eds.): Handbook of Innovation Systems and Developing Countries, Edward Elgar, Cheltenham.

Parrilli, M.D. (2009) 'Collective efficiency, policy inducement and social embeddedness: drivers for the development of industrial districts', Entrepreneurship and Regional Development, Vol. 21, No. 1, pp.1-24.

Parthasarathy, B. (2004) 'India's Silicon Valley or Silicon Valley's India? Socially embedding the computer software industry in Bangalore', International Journal of Urban and Regional Research, Vol. 28, No. 3, pp.1664-1685.

Parthasarathy, B. and Aoyama, Y. (2006) 'From software services to RandD services: local entrepreneurship in the software industry in Bangalore, India', Environment and Planning A, Vol. 38, No. 7, pp.1269-1285.

Patibandla, M. and Petersen, B. (2001) Role of Transnational Corporations in the Evolution of a High-Tech Industry: The Case of India's Software Industry, Draft for working paper, Department of International Economics and Management, Copenhagen Business School, Copenhagen.

Patibandla, M., Kapur, D. and Petersen, B. (2000) 'Import substitution with free trade - case of India's software industry', Economic and Political Weekly, 8-14 April, pp.1263-1270.

Pietrobelli, C. and Rabellotti, R. (2004) Upgrading in Clusters and Value Chains in Latin America. The Role of Policies, Sustainable Development Department Best Practices Series, MSM-124, Interamerican Development Bank.

Porter, M. (1998) 'Clusters and the new economics of competition', Harvard Business Review, November-December, pp.77-90.

Rabellotti, R. (1999) 'Recovery of a Mexican cluster: devaluation bonanza or collective efficiency?', World Development, Vol. 27, No. 9, pp.1571-1585.

Rabellotti, R., Giuliani, E. and Alexander, R. (2014) 'Clusters in the Caribbean: understanding their characteristics, defining policies for their development', VIII Americas Competitiveness Forum 'The Human Imagination at Work', Trinidad and Tobago.

Rajawat, K.Y. (2004) 'Togetherness for survival', Economic Times, 7 July. 
Saxenian, A. (1994) Regional Advantage: Culture and Competition in Silicon Valley and Route 128, Harvard University Press, Cambridge, Massachusetts.

Schmitz, H. (1995) 'Collective efficiency: growth path for small-scale industry', The Journal of Development Studies, Vol. 31, No. 4, pp.529-566.

Schmitz, H. (1999a) 'Collective efficiency and increasing returns', Cambridge Journal of Economics, Vol. 23, pp.465-463.

Schmitz, H. (1999b) 'Global competition and local cooperation: success and failure in the Sinos Valley, Brazil', World Development, Vol. 27, No. 9, pp.1627-1650.

Schmitz, H. (2004) Local Enterprises in the Global Economy: Issues of Governance and Upgrading, Edward Elgar Pub., Cheltenham, UK, Northhampton, MA.

Schmitz, H. and Nadvi, K. (1999) 'Special issue: industrial clusters in developing countries', World Development, Vol. 27, No. 9, pp.1503-1514.

Sridharan, E. (2003) Evolving Towards Innovation?, pp.27-50, Palgrave Macmillan, Houndmills, Basingstoke, Hampshire, New York.

Storper, M. and Venables, A.J. (2004) 'Buzz: face-to-face contact and the urban economy', Journal of Economic Geography, Vol. 4, No. 4, pp.351-370.

STPI-B (2004) Industry Performance Analysis, Software Technology Parks of India, Bangalore [online] http://www.soft.net/perfanalysis.htm\# (accessed 1 December).

STPI-B (2005) Industry Performance Analysis [online] http://www.blr.stpi.in/soft.net/ perfanalysis.htm (accessed 5 August).

Sturgeon, T.J. (2002) 'Modular production networks: a new American model of industrial organization', Industrial and Corporate Change, Vol. 11, No. 3, pp.451-496.

The Economic Times (2002) 'Wipro, TCS wangle $\$ 70$ million Lehman deal', The Economic Times, 7 November.

The Hindu (2002a) 'Bangalore is where it happens', The Hindu Business Line, 28 October.

The Indian Express (2014) [online] http://indianexpress.com (accessed 13 January 2015).

TiE (2004) About Us, The IndUS Entrepreneurs, Bangalore [online] http://www.tieindia.org/ tiebanglore.html (accessed 28 June).

Vang, J. and Asheim, B. (2006) 'Regions, absorptive capacity and strategic coupling with high-tech TNCs: lessons from India and China', Science, Technology and Society, Vol. 11, No. 1, pp.39-66.

Vijayabaskar, M. and Krishnaswami, G. (2003) 'Understanding growth dynamism and its constraints in high technology clusters in developing countries: a study of Bangalore, Southern India', in Sunil, M. and Romijn, H. (Eds.): Innovation, Learning and Technological Dynamism of Developing Countries, pp.179-201, UNU Press, Helsinki.

Wade, R. (2003) Governing the Market: Economic Theory and the Role of Government in East Asian Industrialization, 2nd ed., Princeton University Press, New Jersey, USA, ISBN 9780691117294.

Wibe, M.D. and Narula, R. (2002) 'Interactive learning and non-globalisation: knowledge creation by Norwegian software firms', International Journal of Entrepreneurship and Innovation Management, Vol. 2, Nos. 2-3, pp.224-245.

\section{Notes}

1 Other studies, examining the Indian software industry in general, have paid more attention to external linkages (see for instance Patibandla et al., 2000; Patibandla and Petersen, 2001).

2 There may be forces at play akin to the prisoners' dilemma. If actors communicate, make rules with associated sanctions and develop trust through repeated interactions firms may reach an optimal outcome in terms of beating external competition (cooperation). 
3 This paper draws together the relevant data from a wider study with fuller details and analyses of complementary issues (Lema, 2009). In preparing the study, a comprehensive base of original data was collected: more than 50 key informant interviews were carried out with firm, managers, business associations, public agencies and observers. Participant observation was carried out at producer conferences and trade fairs. Other sources include existing statistics on the Indian and Bangalore-based software industry, government documents, software industry trade-literature, the quality business press, annual reports, and the generally well-developed websites of firms and institutions in the cluster.

4 The SEI-CMM is a model for judging the maturity of the software processes of an organisation. It has become a de facto standard for the quality-assessment of software firms.

5 The Indian Institute of Science was established in the city by the state and the Tata-family in 1909 followed by a large number of polytechnics in the 1920s IISc established itself as a highly merited education institution in terms of engineering and technology, and has two renowned departments: Supercomputer Education and Research Centre (SERC) and Department of Computer Science and Automation (CSA) [Kumar, (2001), p.37f].

6 This also explains the rapid growth regions in India with strong engineering educational institutions such as Mumbai, Noida (outside Delhi), Chennai, Hyderabad and Pune.

7 With regard to computer hardware, the industry has enjoyed favourable conditions as the state has cut import taxes on hardware. In the early days computer sales firms and telecommunication emerged as to service the industry in Bangalore. However, as liberalisation has opened up for the presence of TNCs, the foreign produced hardware is often bought directly from the vendor.

8 This institution also cut down on the bureaucratic hurdles faced by software entrepreneurs by creating a 'single-window' service in all matters relating to software production.

9 While there are no labour organisations associated with the industry, firms develop advanced complementation packages (health insurance, tuition fees for children, etc.) in the competitive race for employees.

10 Specifically the deal, as disclosed, involves that Lehman Brothers will outsource between $\$ 50$ million and $\$ 70$ million to Wipro and TCS annually for an unspecified period (The Economic Times, 2002).

11 Furthermore, for the development of Finacle itself, Infosys has also been cooperating with I-Flex, a successful Indian banking products company.

12 A critique forwarded by informants of higher-end companies was that NASSCOM provides little assistance and efforts concerning the software products companies, e.g., marketing, investment, and intellectual property creation and protection. For instance one respondent said that in relation to taking patents on intellectual property, innovative firms (like his own) had to hire US-based consulting firms on how to do this, as neither NASSCOM or other Indian private firms had the sufficient knowledge in this area. Off course the main focus on services corresponds with the composition of the software industry, but it can also been seen as reinforcing the lock-in to the service driven business model.

13 SPIN is concerned with the spread of knowledge on the protocols for interaction in modularised production networks (the SEI-CMM standard), spurred by networks of lead firms. NASSCOM also has 'quality assurance', i.e., adoption of globally renowned standards (including SEI-CMM, ISO and Six-Sigma) as a key priority. 